ISSN 2414-1143

Научный альманах стран Причерноморья. 2018. Том 15. № 3

DOI 10.23947/2414-1143-2018-15-3-18-22

UDC 1:316+008

\title{
ETHNIC FUNCTIONS OF CULTURE: SOCIAL AND PHILOSOPHICAL ANALYSIS OF ETHNOGRAPHIC RESEARCH
}

\author{
(C) Olga Yu. Kolosova, Vadim N. Goncharov
}

\author{
Krasnodar University of the Ministry of the Interior of the Russian Federation \\ Krasnodar, Russian Federation \\ Institute of the Humanities of the North-Caucasus Federal University \\ Stavropol, Russian Federation \\ science-almanac@mail.ru
}

The article analyzes the phenomenon of culture from a socio-philosophical point of view. According to the authors's view, it is understood as a creative activity of people, because its ethnic functions are manifested in the most diverse spheres: from material production to the spiritual life of society. Usually, when characterizing the ethnic properties of culture, the focus is on those that perform an ethno-differentiating role. And it has certain reasons. However, it would be wrong if such an approach completely overshadowed the ethno-integrating functions of culture. After all, even if properties that distinguish each ethnos among other similar communities are important, the integrating functions of culture remain an indispensable and most important condition for its existence as an integrated system. Due to the interaction of cultures, as well as a certain cultural convergence in the development of peoples, as a rule, the predominant part of ethnic characteristics in the sphere of culture is relative. They act as a common property of several ethnic units, simultaneously distinguishing all of them from some other units of the same type. If we approach this issue abstractly, then, ultimately, it is necessary, almost every component of the culture to consider as relatively specific. Therefore, it is obvious that practically the features that distinguish it primarily from the ethnic communities with which it is in relatively constant contact should be considered as relatively specific features of this or that ethnic community. One more feature of the ethnospecific features of culture that would be worth bearing in mind.: some of them are objectively such a type, some are classified as ethnic selfawareness by this category, playing an important role in the ethnic identification of people. Often, objectively existing ethnically specific properties of a culture and subjectively distinguished ones coincide. However, this is not always the case, because ethnic self-consciousness is often inclined to absolutize the ethnic specificity of individual cultural elements.

Keywords: culture, religion, ethnos, society, public consciousness

[О.Ю. Колосова, В.Н. Гончаров Этнические функции культуры: социально-философский анализ этнографического исследования]

В статье с социально-философских позиций анализируется френомен культуры. По мнению авторов, она понимается как созидательная деятельность людей, поскольку ее этнические функции проявляются в самых разнообразных сфрерах: от материального производства до духовной жизни общества. Обычно при характеристике этнических свойств культуры основное внимание уделяется тем, которые выполняют этнодифференцирующую роль. И это имеет определенные основания. Однако было бы неверно, если бы такой подход полностью заслонил этноинтегрирующие функции культуры. Ведь при всей значимости свойств, выделяющих каждый этнос среди других аналогичных общностей, непременным и важнейшим условием его существования как целостной системы остаются интегрирующие функции культуры. В силу взаимодействия культур, а также определенной культурной конвергентности в развитии народов преобладающая часть этнических особенностей в сфере культуры имеет, как правило, относительный характер. Они выступают как общее свойство нескольких этнических единиц, отличающее одновременно всех их от некоторых других единиц того же типа. Если подойти к данному вопросу абстрактно, то, в конечном счете, придется, чуть ли не каждый компонент культуры рассматривать как относительно специфический. Поэтому относительно специфическими чертами той или иной этнической общности, очевидно, следует практически считать только черты, отличающие ее, в первую очередь, от общностей, с которыми она находится в сравнительно постоянных контактах. Следует иметь в виду еще одну особенность этноспецифических черт культуры: 
часть из них объективно являются таковыми, часть причисляется к этой категории этническим самосознанием, играя важную роль в этнической идентификации людей. Нередко объективно существующие этнически специфические свойства культуры и субъективно выделяемые такого рода свойства совпадают. Однако это бывает далеко не всегда, ибо этническое самосознание часто склонно абсолютизировать этническую специфику отдельных элементов культуры.

Ключевые слова: культура, религия, этнос, общество, общественное сознание

Olga Yu. Kolosova - PhD of philosophy, professor. Krasnodar University of the Ministry of the Interior of the Russian Federation. Krasnodar, Russian Federation.

Колосова Ольга Юрьевна - доктор философских наук, профессор. Краснодарский университет Министерства внутренних дел Российской Федерации. Краснодар, Россия.

Vadim N. Goncharov - PhD of philosophy, professor. Institute of the Humanities of the North-Caucasus Federal University. Stavropol, Russian Federation.

Гончаров Вадим Николаевич - доктор фрилософских наук, профессор. Гуманитарный институт Северо-Кавказского федерального университета. г. Ставрополь, Россия.

In the system of social development, culture performs numerous functions. There is a "need to consider ... these functions and dispositions of social structures" [2, p. 168-177]. Among them, it seems legitimate to emphasize the ethnic function, which the aggregate of its ethno-differentiating and ethno-integrating properties performs [4, p. 52]. These latter properties of culture, which are very significant in the context under consideration, are intimately connected with its other functions and often act as one of their sides. Moreover, in fact, ethnic functions as a kind of an addition to the main functions of culture in society contribute to the "dialogue of cultures in the context of the development of modern civilization" [9, p. 145-160].

The ethnos integrating cultural components are not homogeneous. They differ not only in their main functions, but also in spatial parameters. And this gives the culture of the ethnos a kind of multilayering characteristic. In turn, in this kind of layering several levels can be distinguished. The most in-depth and at the same time macro-scale is the one to which "... the quality of a person and the ability of social subjects to interact with the environment" is related [7, p. 282-284].

One of the immediate tasks of ethnographic science is studying of so-called metaethnic communities [5, p. 15-42]. This refers to education, covering several main ethnic divisions, but with ethnic properties of lesser intensity than each of these divisions. At the same time, meta-ethnic communities are distinguished by an extraordinary diversity in their genesis, system-forming components, and scales. So, like the main ethnic units ethnic groups, metaethnic communities can be subdivided into ethno-social and proper ethnic ones. The first one in the history of nations most often appear as meta-ethnic political communities, the second one only as meta-ethnocultural. Since in the latter case certain components of a culture serve as the main objective criterion for identifying ethnocultural meta-communities, these communities, in turn, can be meta-ethnolinguistic, metaethno-confessional, meta-ethno-economic. At the same time, in addition to the commonality of the corresponding main component of culture (language, religion, type of economy), such entities have common features in some other related areas of everyday culture, that is, they are holistic.

The cultural layers that extend to several ethnic groups have one common feature: the overwhelming majority of them, entirely or at least largely pre-industrial, "... are closely related to a wide range of studies of human existence as a whole" [6, p. 127-133]. Meanwhile, as is known, in the modern urbanized society in the course of the internationalization of the entire life of peoples an ever growing interethnic cultural stratum 
of a new generation is being created. This layer, which can be conditionally called an urbanized culture, undoubtedly plays a significant role not only in the rapprochement of ethnic groups, but also in their internal integration. In particular, the most essential functions in the latter case fall on modern means of mass communication. At the same time, the urbanized culture is able to perform ethnic functions, incarnating in specifically ethnic forms. The expression of elements of spiritual culture international in their content in national language forms is especially significant in this respect.

Each significant component of the ethnos in its own way expresses ethnic specificity, moreover, it is far from being the same in different distinct historical situations. Accordingly, the definition of the tasks of ethnography in the study of the ethnodifferentiating properties of the culture of an ethnos implies its component consideration.

Acting as the main science, considering the actually functioning traditional forms of material culture, ethnography is forced to provide its concrete sociological study. But unlike the approach of other disciplines to material culture, ethnography is ultimately interested in the performance of its components of ethnic functions. It should also be emphasized that, since ethnic characteristics are predominantly traditional forms of material culture, they are usually under the focus of attention.

Turning to the ethnic functions of that part of culture, which is expressed in the behavior of people, one should first of all take into account that in any human group it is not a direct response to external stimuli, but is inderectly done by culture. For this, it is necessary to know meanings of gestures, sounds, movements, that is, the performance of a sign function by culture.

The sign function of a culture is called significative (literally: signifying, attributing meaning). Of course, the study of this function of culture is of considerable interest for ethnography, as signs and meanings perform an ethno-integrating and ethnodifferentiating role. At the same time, the internal significative unity of the culture of an ethnos, that is, the information integrated in its components, reading in a certain way in its general context and thereby programming specific activity, at the same time performs an ethno-differentiating function, distinguishing one people from another.

Significant function of culture is closely connected with two other functions: cognitive and communicative. Signs and meanings allow a person to recreate a picture of the world. With the help of names, values and assessments, the continuum (continuity) of the objective world is divided into significant fragments, which, in turn, are differentiated and integrated in relation to the tasks of practical and spiritual activity. In different cultures, this division receives a different conceptual and linguistic expression, it corresponds to different sets of names and meanings.

As for the communicative function of culture, it is of particular importance for ethnic groups, providing each of them with typical informational links - a specific way of transmitting ethnocultural information. The main role in the reproduction of the ethnos belongs to intergenerational, diachronic ethnocultural information. "The presence of these continuous diachronic information connections between successive generations of an ethnos is due to its continuity and stability over time" [1, p. 8-30]. But along with the diachronic, synchronous information is important for the functioning of the ethnos, ensuring its spatial stability [1, p. 22] and cultural integration.

Of all the components of culture in the broadest sense of the word, language usually express ethnic functions the most distinctly. It is not by chance that in the scientific literature, in determining the main features of both ethnic formations in general and individual types of their own, language has long been generally put forward in the first place, and there are sufficient grounds for this.

The components of spiritual culture are closely related to the ethical, legal and 
religious forms of public consciousness, which often bear a significant ethnic content. Many of these components of spiritual culture have long been considered as deserving special attention in ethnographic research.

First of all, this refers to the moral and ethical standards of the peoples of the world, the study of which is sometimes defined as one of the main tasks of ethnographic science. However, if we do not take into account the characteristics of moral norms in various peoples in certain generalizing works [8], then we have to admit that very little has been done in the ethnographic study of this sphere of everyday consciousness (especially in relation to the peoples of developed countries).

The attention of ethnographers is extremely unevenly distributed in the study of legal norms, which together with moral norms constitute the core of the sociological culture. It remains relatively significant in relation to the archaic norms of law, to customary law.

Considerable interest has long been shown by ethnography to the religions of the peoples of the world. In no small measure this is due to the fact that religion is the most important component of peoples' consciousness. The attention of ethnography to it is directly dependent on the fulfillment of its ethnic functions. This, above all, determines the selectivity of its ethnographic study. Firstly, one of the subsystems of the ethnos has attracted the attention of ethnographers for a long time and it is folk art. A common basis for determining the relationship of ethnography with the art is that history disciplines in the study of various types of folk art, should be the fulfillment by each of them of aesthetic and ethnic functions. At the same time, it should be immediately emphasized that folk art has ethnic specificity not only in primitiveness, but throughout its history. And consequently, it would be wrong to assume that the subject of the ethnography of art is limited only by the artistic creativity of the peoples who have lagged behind in their development.

Along with ethical, legal, religious, and artistic forms of social consciousness, interior culture in a certain sense includes such complex mental formations as value orientations, social attitudes, ideals, and beliefs that "effectively reflect the characteristics of social dynamics" [3, p. 95-100]. The study of these entities as such is primarily a matter of psychology. However, they, as a rule, have a specific coloring for each ethnos and, therefore, should not remain outside the field of vision of ethnography, more precisely, its such subdiscipline as ethnopsychology. In addition, in this regard, it is significant that recently attempts have been made in the course of ethnosociological studies to reveal the specificity of value orientations in individual ethnic groups. Perhaps more importantly, along with theoretical research on the problems of ethnic self-consciousness, steps have been taken to study concretely ethnic (national) attitudes, that is, orientations to a particular behavior during inter-ethnic contacts.

\section{Лumepamypa}

1. Арутюнов С.А., Чебоксаров Н.Н. Передача информации как механизм существования этносоциальных и биологических групп человечества // Расы и народы: Современные этнические и расовые проблемы: Ежегодник. М.: Наука, 1972. Вып. 2. С. 8-30.

2. Бакланова О.А., Бакланов И.С. Современная российская социальность в контексте социального конструкционизма // Вопросы социальной теории. 2015. Т. 7. № 1-2. С. 168-177.

3. Бакланова О.А., Бакланов И.С., Ерохин А.М. Методологические конструкты исследования социальности современного общества // Историческая и социально-образовательная мысль. 2016. Т. 8. № 3-1. С. 95-100.

4. Бромлей Ю.В. Этнос и этнография. М.: Наука, 1973. 280 с. 
5. Брук С.И., Чебоксаров Н.Н. Метаэтнические общности // Расы и народы: Современные этнические и расовые проблемы: Ежегодник. М.: Наука, 1976. Вып. 6. С. 15-42.

6. Камалова О.Н. Становление и развитие неклассических подходов понимания интуиции в первой половине XX века // Экономические и гуманитарные исследования регионов. 2013. № 4. С. 127-133.

7. Лобейко Ю.А. Социальная активность личности в обществе: социальнопедагогические аспекты формирования // European Social Science Journal. 2014. № 7-2(46). С. 282-284.

8. Мораль: сознание и поведение. М.: Наука, 1986. 208 с.

9. Несмеянов Е.Е. «Цивилизация молодых»: идея и реальность // Гуманитарные и социальные науки. 2013. № 6. С. 145-160.

\section{References}

1. Arutyunov S.A., Cheboksarov N.N. Peredacha informatsii kak mekhanizm sushchestvovaniya etnosotsialnyh i biologicheskih grupp chelovechestva // Rasy i narody: Sovremennye etnicheskie i rasovye problemy: Ezhegodnik. M.: Nauka, 1972. Vyp. 2. P. 8-30. (in Russian).

2. Baklanova O.A., Baklanov I.S. Sovremennaya rossijskaya sotsialnost v kontekste sotsialnogo konstruktsionizma // Voprosy sotsialnoj teorii. 2015. T. 7. № 1-2. pp. 168-177. (in Russian).

3. Baklanova O.A., Baklanov I.S., Erohin A.M. Metodologicheskie konstrukty issledovaniya sotsialnosti sovremennogo obshchestva // Istoricheskaya i sotsial'noobrazovatelnaya mysl'. 2016. T. 8. № 3-1. pp. 95-100. (in Russian).

4. Bromlej Y.V. Etnos i etnografiya. M.: Nauka, 1973. 280 p. (in Russian).

5. Bruk S.I., Cheboksarov N.N. Metaetnicheskie obshchnosti // Rasy i narody: Sovremennye etnicheskie i rasovye problemy: Ezhegodnik. M.: Nauka, 1976. Vyp. 6. P. $15-42$.

6. Kamalova O.N. Stanovlenie i razvitie neklassicheskih podhodov ponimaniya intuitsii $\mathrm{v}$ pervoj polovine XX veka // Ekonomicheskie i gumanitarnye issledovaniya regionov. 2013. №4. P. 127-133. (in Russian).

7. Lobejko YU.A. Sotsialnaya aktivnost lichnosti $v$ obshchestve: sotsialnopedagogicheskie aspekty formirovaniya // European Social Science Journal. 2014. № 7-2(46). pp. 282-284.

8. Moral: soznanie i povedenie. M.: Nauka, 1986. 208 p.

9. Nesmeyanov E. E. «Tsivilizatsiya molodyh»: ideya i real'nost // Gumanitarnye i sotsialnye nauki. 2013. № 6. pp. 145-160. 